\title{
Induced Anti-Tumor Antigen-specific Antibody
}

National Cancer Institute

\section{Source}

National Cancer Institute. Induced Anti-Tumor Antigen-specific Antibody. NCI Thesaurus.

Code C129920.

An antibody that recognizes a tumor-associated antigen (TAA) and is induced and

expressed following immunization by a therapeutic antibody targ eting the same TAA. 